Discussion Paper No. 12-073

\title{
Estimating the Wage Premium of Collective Wage Contracts - Evidence from Longitudinal Linked Employer-Employee Data
}

Nicole Guertzgen

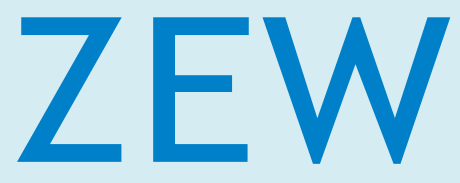

Zentrum für Europäische Wirtschaftsforschung $\mathrm{GmbH}$

Centre for European Economic Research 
Discussion Paper No. 12-073

\section{Estimating the Wage Premium of Collective Wage Contracts - Evidence from Longitudinal Linked Employer-Employee Data}

Nicole Guertzgen

Download this ZEW Discussion Paper from our ftp server:

http://ftp.zew.de/pub/zew-docs/dp/dp12073.pdf

Die Discussion Papers dienen einer möglichst schnellen Verbreitung von neueren Forschungsarbeiten des ZEW. Die Beiträge liegen in alleiniger Verantwortung der Autoren und stellen nicht notwendigerweise die Meinung des ZEW dar.

Discussion Papers are intended to make results of ZEW research promptly available to other economists in order to encourage discussion and suggestions for revisions. The authors are solely responsible for the contents which do not necessarily represent the opinion of the ZEW. 
Non-technical summary: Drawing on a large-scale German Linked EmployerEmployee data set spanning the time period 1995-2008, this paper provides new evidence on the collective bargaining wage premium in western Germany. By using longitudinal data, we seek to improve on recent evidence which relies on cross-sectional data. Unlike the previous literature, we assess the extent to which differences in wages between workers in covered and uncovered firms result from a non-random selection of workers and firms upon time-invariant unobservables into the different regimes. The fact that we observe employers changing their contract status over time provides us with the opportunity to measure the relative wage gains or losses of workers employed in firms that change their contract status.

Taken together, our analysis of separate transitions suggests that workers in firms leaving industry-level bargaining may incur wage losses relative to those workers who are employed by "stable" firms. However, adjusting the estimates for differential time trends supports the notion that plants changing from industry-level contracts to no coverage experience more negative time-specific shocks than stable plants, thereby confirming the result that there is no "true" wage effect of leaving wage bargaining.

For firm-level contracts, the analysis of separate transitions shows that joining firm-level bargaining from no-coverage may be associated with a positive wage premium, whereas the transitions between firm and industry-level contracts tend to give rise to negative wage premiums of firm-level contracts. This finding is consistent with firm-level bargaining being initiated by employers who were formerly covered by an industry-level contract and argues against the view that unions tend to enforce such contracts in order to secure above average wage gains in highly successful firms. 
Das Wichtigste in Kürze: Die vorliegende Studie liefert neue Evidenz zu Lohnprämien der Tarifbindung für Westdeutschland. Im Gegensatz zur bisherigen Literatur werden Längsschnittsdaten des LIAB für den Zeitraum 1995-2008 ausgenutzt, um zu überprüfen, inwiefern durch Tarifverträge hervorgerufene Lohndifferenziale eine Selektion von überdurchschnittlich produktiven Beschäftigten bzw. von Hochlohn-Unternehmen in die Tarifbindung widerspiegeln. Zur Identifikation des Effekts der Tarifbindung auf das Lohnniveau werden Wechselbetriebe identifiziert, die ihren Tarifbindungsstatus über die Zeit hinweg ändern. Durch den Vergleich von Lohnveränderungen von Beschäftigten in Wechselbetrieben mit denen von Beschäftigten in "stabilen" Betrieben wird zeitkonstanter unbeobachtbarer Heterogenität auf Individual- und Betriebsebene Rechnung getragen. Eine mögliche Verzerrung durch die Korrelation zeitvariierender Schocks mit den Regimewechseln wird durch Unterschiede im Lohnwachstum zwischen Wechselbetrieben und stabilen Betrieben in den Perioden vor den Regimewechseln abgeschätzt.

Die Analyse der separaten Übergänge zwischen den einzelnen Regimen zeigt, dass Beschäftigte in Betrieben, die die Flächentarifbindung verlassen, ein geringeres Lohnwachstum erfahren als Beschäftigte in stabilen Betrieben. Gerade für Betriebe, die sich vollständig der Tarifbindung entziehen, zeigt sich jedoch, dass das Lohnwachstum im Vergleich zu stabilen Betrieben bereits vor dem Wechsel einem ungünstigeren Trend unterlag. Die Bereinigung der geschätzten Lohnprämien um diesen Trendunterschied zeigt schließlich, dass sich insgesamt keine signifikanten Lohneffekte mehr nachweisen lassen.

Bei den Übergängen zu Haustarifverträgen deuten die Ergebnisse für Beschäftigte in Betrieben, die vorher keinem Tarifvertrag unterlagen, auf signifikante positive Lohnprämien hin, während ein Wechsel von Flächen- zu Haustarifverträgen mit negativen Lohnprämien verbunden ist. Diese Ergebnisse bleiben durch die Trendbereinigung erhalten. Letzteres Ergebnis deutet daraufhin, dass Wechsel von Flächenzu Haustarifverträgen eher durch Arbeitgeber initiiert werden und widerspricht der üblichen Vorstellung, dass Gewerkschaften in vormals flächentarifgebundenen Betrieben Haustarifverträge dazu nutzen, um höhere Löhne durchzusetzen. 


\title{
Estimating the Wage Premium of Collective Wage Contracts - Evidence from Longitudinal Linked Employer-Employee Data
}

\author{
N. Guertzgen \\ Centre for European Economic Research, Mannheim*
}

September 2012

\begin{abstract}
Using a large-scale linked-employer-employee data set from western Germany, this paper presents new evidence on the wage premium of collective bargaining contracts. In contrast to previous studies, we seek to assess the extent to which differences in wages between workers in covered and uncovered firms arise from the non-random selection of workers and firms into collective bargaining coverage. By measuring the relative wage changes of workers employed in firms that change contract status, we obtain estimates that depart considerably from previous results relying on cross-sectional data. Results from analysing separate transitions show that leaving industry-level contracts is associated with subsequent wage losses. However, the results from a trendadjusted difference-in-difference approach indicate that the particularly the transitions to no-coverage appear to be associated with negative shocks. Overall, our findings provide no evidence of a "true" wage effect of leaving wage bargaining, once differences in pre-transition wage growth are accounted for.

Keywords: Union Wage Premium; Collective Bargaining Coverage

JEL-Code: J31; J51
\end{abstract}

\footnotetext{
${ }^{*}$ Centre for European Economic Research, Department of Labour Markets, Human Resources and Social Policy, L 7.1, 68161 Mannheim, Germany, E-Mail: Guertzgen@zew.de. This paper is a strongly revised version of an earlier version entitled "The effect of firm- and industry-level contracts on wages - evidence from longitudinal linked employer-employee data". I would like to thank Bernd Fitzenberger, Hendrik Jürges, Michael Maier and Claus Schnabel for valuable comments and discussions on earlier versions of this paper. I also thank Holger Alda and Peter Jacobebbinghaus for help with the data at the Research Data Centre (FDZ) of the Federal Employment Services (BA) at the Institute for Employment Research (IAB), Nuremberg. The institutions mentioned are not responsible for the use of the data in this publication. Financial support from the German Research Foundation (DFG) under the Program "Potentials for more flexibility on heterogeneous labour markets" (Grant-No. GU 1081/1-3) is gratefully acknowledged.
} 


\section{Introduction}

The question of whether unions are able to drive a wedge between the wages of comparable workers in the union and non-union sector is of considerable interest to an understanding of the wage determination process. While the empirical literature for the U.S. and the U.K. has primarily focused on union membership as a determinant of individual wages (e.g., Farber 1983, Freeman 1984, Card 1996, Lemieux 2000, Andrews et al. 1998, Blanchflower and Bryson 2010), in continental Europe it is rather collective bargaining coverage that matters. The reason is that extension mechanisms, which are widespread in European economies, can widen the coverage of collective bargaining agreements irrespective of individual workers' union membership status. Given the differences in institutional settings in which bargaining may take place, a further question that has continued to motivate economic research is how firm-level contracts compare to industry-level contracts.

There is a large theoretical literature on the link between the bargaining structure and wages (Calmfors and Driffill 1988, Moene et al. 1993), whose predictions have been tested in a number of cross-country studies (Calmfors and Driffill 1988, Soskice 1990, OECD 1997, Calmfors 2001). More recently, with the increasing availability of linked employer-employee data, the relationship between collective bargaining coverage and wage outcomes has attracted renewed interest. By providing both information on wages at the individual level and collective bargaining coverage at the employers' level, such data permit to exploit intra-national variations in the bargaining structure to assess its impact on the level and structure of wages. Examples include Hartog et al. (2002) for the Netherlands, Cardoso and Portugal (2005) for Portugal, Stephan and Gerlach (2005) and Fitzenberger et al. (2008) for Germany as well as Card and de la Rica (2006) for Spain. While Hartog et al. (2002) fail to detect any positive effect of bargaining coverage on wages, Stephan and Gerlach (2005) document sizeable wage premiums ranging between 7 and 11 log points for industry and firm-level contracts. Fitzenberger et al. (2008) find that the share of employees subject to a collective bargaining contract is associated with a positive 
wage mark-up, which is found to be larger under firm-level contracts. In a similar vein, the evidence by Cardoso and Portugal (2005) and Card and de la Rica (2006) points to higher wage premiums under firm-level as compared to industry-level contracts.

Our paper presents new evidence on the collective bargaining wage premium, using a large-scale German linked employer-employee data set. Our analysis of collective bargaining coverage and wages for Germany is motivated by several reasons. To begin with, and most importantly, previous linked employer-employee data evidence on the collective bargaining effect relies on cross-sectional data and typically fails to address the selection problem. ${ }^{1}$ As has already been argued in the literature on union membership wage effects, selection is likely to be a major issue, if collective bargaining contracts raise wages above the competitive wage and compress the returns to observable attributes. In this case, observed and unobserved productivity components are likely to be negatively correlated since, e.g., workers with low observed skills will only be hired if they exhibit high unobserved skills (see Farber 1983, Card 1996, Lemieux 2000). In order to deal with such a potential selection bias, the evidence presented in this paper is based on a longitudinal data set. Hence, unlike the studies cited above, we seek to assess the extent to which differences in wages between workers in covered and uncovered firms result from a non-random selection of workers and firms upon time-invariant unobservables into the different regimes. The fact that we observe employers changing their contract status over time provides us with the opportunity to measure the relative wage gains or losses of workers employed in firms that change their contract status. Clearly, such an identification strategy rules out the endogeneity of a change in contract status, since establishments changing contract status may experience different timespecific shocks than those that retain their contract status. While we are not able to deal with this endogeneity problem by exploiting an exogenous variation in contract status, we shall attempt to assess the severity of this problem. The strategy we

\footnotetext{
${ }^{1}$ DiNardo and Lee (2004) address the selectivity issue by using a regression discontinuity design. However, their analysis is based upon an establishment-level data set.
} 
pursue here is to analyse transitions between the regimes separately and to adopt a trend-adjusted difference-in-difference estimator which permits us to account for differences in time-specific shocks across establishments that change contract status and those that do not.

Secondly, the German case provides an instructive example for continental European extension mechanisms. Although negotiated wages strictly speaking only apply to union members, firms generally extend wage settlements to non-member employees as well. Moreover, central wage contracts may also apply to non-member firms if an agreement is declared to be generally binding. As a consequence, despite declining union membership among employees, which to date has reached a relatively modest level of roughly 20 per cent, collective bargaining coverage is still of crucial importance to the wage-setting process in Germany. For example, collective bargaining contracts in 2007 were estimated to cover about 39 per cent of employers and about 63 per cent of employees in western Germany (Ellguth and Kohaut 2008).

A final, third, motivation is based on the fact that the institutional environment in Germany is characterised by the coexistence of different bargaining regimes. Collective bargaining contracts may take the form of either firm-level contracts or industry-level contracts. Moreover, in recent years wage determination without any bargaining coverage has become more important. Thus, with the increasing importance of the uncovered sector it is possible to compare wage outcomes under firm-level and industry-level contracts as well as for workers in covered and uncovered firms.

The remainder of the paper proceeds as follows. Section 2 provides some institutional background information on German wage determination. Section 3.1. sets out the estimation strategy for quantifying the wage premiums under different collective wage contracts. While Section 3.2. provides a description of the data set used, Section 3.3. presents the estimation results. The final Section 4 concludes. 


\section{Institutional Background}

In this section we provide some background on how collective bargaining affects German wage determination. Within the system of wage bargaining, regional and industry-wide collective wage agreements (Flächentarifverträge) rank among the most important contract type. Such centralised wage contracts are negotiated between an industry-specific trade union and an employers' association. While being legally binding on all member firms of the employers' association and on all employees who are members of the trade union, member firms generally extend the wage settlement to the non-member labour force as well. The reason is that non-member employees who would receive a lower wage may be expected to join the union anyway in order to benefit from higher union wages. Moreover, central wage contracts may also apply to non-member firms and their employees if an agreement is declared to be generally binding by the Federal Ministry of Labour. Finally, there are voluntary extension mechanisms, i.e. firms without any legally binding agreement may voluntarily apply a central industry agreement. In general, bargained wages under industry-level contracts merely represent a lower bound on wages, i.e. firms are free to pay wages above the negotiated rate. However, in contrast to other European countries, there is no two-tier system with subsequent firm-level agreements, since higher wages than those stipulated in the centralised agreement are paid on a voluntary basis and do not arise from a legally binding supplementary firm-level contract. Overall, the predominance of industry-level bargaining along with the synchronisation of different collective agreements has led economists to characterise the German system of wage bargaining as medium-centralised with a high degree of coordination (Calmfors and Driffill 1988, Soskice 1990, OECD 2004).

Even though industry-level bargaining may be still be viewed as the predominant form of wage determination, in recent decades German industrial relations have witnessed a clear tendency towards alternative forms of wage determination. Evidence from the IAB-Establishment Panel indicates that the proportion of establishments with a legally binding industry-wide contract fell economy-wide from 48 
per cent to 36 per cent over the time period 1996 to 2007 in western Germany. ${ }^{2}$ This phenomenon is largely the result of a considerable drop in firms' membership in employers' associations. ${ }^{3}$ Employers leaving their employers' association either have the option of concluding a firm-specific contract with their respective industry union or becoming uncovered. There is likely to be a certain time lag before such a change comes into effect, as employers face two legal constraints when changing contract status: First, according to the German Act on Collective Agreements ("Tarifvertragsgesetz") employers leaving their employers' association are subject to a validity time limit according to which the contract terms continue to apply until the respective contract has expired. Note that this also holds true for leaving firmlevel arrangements. Second, even if a contract has already expired, the law dictates that employers replace the contract terms by individual contracts or, alternatively, by a firm-specific contract in order to be able to depart from previous contractual arrangements. However, at this point it is worth noting that the decision to leave industry-level bargaining is not necessarily left to the employer's discretion. For instance, even if a firm prefers to stay uncovered, its union may attempt to enforce a firm-specific contract. Whether such an attempt succeeds, ultimately depends on firm-specific union density. The underlying rationale is that the union's ability to present the employer with a credible threat to strike may be expected to increase considerably with the proportion of workers who are organised in that union. ${ }^{4} \mathrm{Al}-$ though the absolute number of firm-specific collective wage agreements has increased markedly since the beginning of the 1990s, this increase cannot explain the declining importance of industry-level contracts. Evidence from the IAB-Establishment Panel indicates that the share of establishments reporting the existence of a firmlevel contract fell from 10 to 3 per cent over the time period 1996 to 2007. ${ }^{5}$ Thus, the

\footnotetext{
${ }^{2}$ Own calculations based on IAB-Establishment Panel.

${ }^{3}$ For example, the employers' association "Gesamtmetall" reports that the share of employees at member firms as a percentage of total employment in the metal and electrical industry fell in western Germany from 72 per cent to 55 per cent over the time period 1991 to 2007 (Gesamtmetall 2012).

${ }^{4}$ Indirect evidence for this is provided by Fitzenberger et al. (2008). Using a cross-section from the German Salary and Wage Structure Survey the authors find the effect of firm-specific collective bargaining coverage increase with the aggregate propensity of union membership.

${ }^{5}$ Own calculations based on IAB-Establishment Panel. It should be noted here that part of the
} 
decline in industry-level coverage rather resulted in an increasing share of uncovered establishments. In uncovered firms wage determination may either take the form of individual wage contracts or of plant-specific agreements (Betriebsvereinbarungen) between works councils and the management. Even though German legislation prohibits works councils from negotiating about issues that are normally dealt with in collective agreements, they are widely recognised as playing a crucial role in wage determination (see e.g., Hassel 1999, Hübler and Jirjahn 2003).

\section{Empirical Analysis}

\subsection{Estimation Strategy}

To quantify the collective bargaining wage premiums, we consider a wage equation taking the following form:

$$
\ln w_{i t}=\mu+\gamma_{C} \cdot C_{j t}+\gamma_{F} \cdot F_{j t}+\beta \cdot x_{i t}^{\prime}+\delta \cdot u_{i}^{\prime}+\eta \cdot z_{j t}^{\prime}+\rho \cdot q_{j}^{\prime}+\nu_{i j t}
$$

where the error component may be written as

$$
\nu_{i j t}=\alpha_{i}+\phi_{j}+\lambda_{j t}+\epsilon_{i t}
$$

There are $i=1, \ldots, N$ individuals, and $N^{*}=\sum T_{i}$ total worker-year observations. As we use matched worker-establishment data, $j$ refers to the establishment that employs individual $i$ at time $t$, i.e., we strictly speaking have $j=j(i, t)$, with $j=1, \ldots, J$. The dependent variable, $\ln w_{i t}$, is the individual log daily wage. The explanatory variables of main interest are $C_{j t}$ and $F_{j t}$, which are indicator variables taking on the value of unity if the establishment that employs individual $i$ at time $t$ is subject to a centralised industry-level or a firm-level contract, respectively. $x_{i t}^{\prime}$ represents a vector of time-varying individual covariates with a coefficient vector $\beta$, while $u_{i}^{\prime}$ denotes a vector of individual time-constant characteristics with a coefficient vector $\delta$. Similarly, $z_{j t}^{\prime}$ and $q_{j}^{\prime}$ represent time-varying and time-constant

decline in firm-level coverage might have been caused by a change in the survey question concerning firm-level contracts. See also Footnote 23. 
$j$-level covariates with coefficient vectors $\eta$ and $\rho$. Time dummies are included to capture common macroeconomic effects. Finally, in eq. (2) the unobserved component comprises an individual unobserved effect, $\alpha_{i}$, establishment-specific unobserved heterogeneity, $\phi_{j}$, a time-varying plant-specific error term, $\lambda_{j t}$ as well as a time-varying individual component $\epsilon_{i t}$.

In our estimation strategy, we first focus on a simple pooled Ordinary Least Squares (POLS) specification of eq. (1), in which neither $\alpha_{i}$ nor $\phi_{j}$ are controlled for. To control for the unobserved firm heterogeneity $\phi_{j}$, we then proceed to allow for establishment fixed effects. With establishment-level fixed effects, time-constant establishment variables $q_{j}^{\prime}$ are eliminated, such that the coefficient vector $\rho$ cannot be identified. The wage premiums of collective contracts are thus identified from establishments changing contract status. To assess the extent to which withinestablishment changes of contract status are associated with systematic changes in workers' unobservable skills, we then turn to a fixed-effects specification which eliminates $\alpha_{i}$ as well as $\phi_{j}$. To remove both $\alpha_{i}+\phi_{j}$, we first-difference eq. within each individual-establishment combination, also referred to as individualestablishment-'spells' (Andrews et al. 2006). Defining $\theta_{s}=\alpha_{i}+\phi_{j}$ in eq. (1) as the unobserved spell-level effect for spell $s$, first-differencing of eq. (1) yields:

$$
\Delta \ln w_{i t}=\gamma_{C} \cdot \Delta C_{j t}+\gamma_{F} \cdot \Delta F_{j t}+\beta \cdot \Delta x_{i t}^{\prime}+\eta \cdot \Delta z_{j t}^{\prime}+\Delta \lambda_{j t}+\Delta \epsilon_{i t},
$$

where first-differencing within each spell sweeps out $\theta_{s}$. Thus, the coefficients on $\Delta C_{j t}$ and $\Delta F_{j t}$ will yield a consistent estimator of the wage premiums as long as $\Delta C_{j t}$ and $\Delta F_{j t}$ are uncorrelated with $\Delta \lambda_{j t}$ and $\Delta \epsilon_{i t}$. Finally, to assess the impact of collective bargaining coverage on the overall wage structure, we will also estimate a fully interacted model, which includes interaction terms of all covariates with the contract status dummies. The interacted regressors are expressed in terms of deviations from their sample means, allowing us to interpret the estimated coefficient on industry and firm-level contracts as the wage premium for a worker with the average characteristics of the full sample. As a result, the interacted specification 
reads as

$$
\begin{aligned}
& \Delta \ln w_{i t}=\gamma_{C} \cdot \Delta C_{j t}+\gamma_{F} \cdot \Delta F_{j t}+\beta \cdot \Delta x_{i t}^{\prime}+\eta \cdot \Delta z_{j t}^{\prime}+\Delta \lambda_{j t}+\Delta \epsilon_{i t}, \\
& +\beta_{C} \cdot\left(C_{j t}\left(x_{i t}^{\prime}-\bar{x}\right)-C_{j t-1}\left(x_{i t-1}^{\prime}-\bar{x}\right)\right)+\delta_{C} \cdot \Delta C_{j t} \cdot\left(u_{i}^{\prime}-\bar{u}\right) \\
& +\eta_{C} \cdot\left(C_{j t}\left(z_{j t}^{\prime}-\bar{z}\right)-C_{j t-1}\left(z_{j t-1}^{\prime}-\bar{z}\right)\right)+\rho_{C} \cdot \Delta C_{j t} \cdot\left(q_{j}^{\prime}-\bar{q}\right) \\
& +\beta_{F} \cdot\left(F_{j t}\left(x_{i t}^{\prime}-\bar{x}\right)-F_{j t-1}\left(x_{i t-1}^{\prime}-\bar{x}\right)\right)+\delta_{F} \cdot \Delta F_{j t} \cdot\left(u_{i}^{\prime}-\bar{u}\right) \\
& +\eta_{F} \cdot\left(F_{j t}\left(z_{j t}^{\prime}-\bar{z}\right)-F_{j t-1}\left(z_{j t-1}^{\prime}-\bar{z}\right)\right)+\rho_{F} \cdot \Delta F_{j t} \cdot\left(q_{j}^{\prime}-\bar{q}\right)+\Delta \lambda_{j t}+\Delta \epsilon_{i t} .
\end{aligned}
$$

From eqs. (3) and (4) it becomes clear that spell first-differencing eliminates timeconstant individual characteristics $u_{i}^{\prime}$ as well as time-constant establishment variables $q_{j}^{\prime}$, so that both coefficient vectors $\delta$ and $\rho$ cannot be identified. Only the interaction coefficients $\delta_{r}, \rho_{r}, r=C, F$, are identified from variations in contract status, i.e. unless $\Delta C_{j t} \neq 0$ and $\Delta F_{j t} \neq 0$. For this reason, it is common to subsume observable time-constant and unobservable attributes into one single individual and establishment effect, i.e. $\varphi_{i}=\delta \cdot u_{i}+\alpha_{i}$ as well as $\vartheta_{j}=\rho \cdot q_{j}+\phi_{j}$.

Eqs. (3) and (4) clarify that identification based upon spell differencing relies on the assumption that a change in contract status is uncorrelated with time-specific unobservables. This assumption rules out that, e.g., establishments changing contract status are subject to different time-specific unobservables than those that retain their contract status. Clearly, it is easy to imagine situations in which this assumption will be violated. On the employer's side, for example, leaving collective bargaining might be systematically correlated with negative developments. On the union's side, however, enforcing a firm-level contract might be correlated with positive shocks if unions are more likely to do so in better times and successful firms (DiNardo and Lee 2004). In such a case, identification of the contract wage premium requires instrumental variables that affect contract status but not wages. Unfortunately, it is hard to think of any variables satisfying these requirements. ${ }^{6}$ However, we attempt

\footnotetext{
${ }^{6}$ A potential source of exogenous variation might stem from extension mechanisms as discussed in Section 2. However, a problem with such an approach is that the majority of contracts that are declared to be generally binding concern working-time and holiday regulations. Only a small minority of extended contracts deal with wage settlements. As the latter do not exhibit sufficient variation across industries and regions, we do not pursue this strategy further.
} 
to assess the severity and direction of a potential endogeneity bias. To do so, we separately analyse transitions from one regime to the other and adopt for each time period a trend-adjusted difference-in-difference estimator as discussed in Bell et al. (1999) and Blundell and Costa Dias (2002). Consider for example establishments that switch from industry-level bargaining to no-coverage. Moreover, let us define individuals experiencing this transition as the program group and those who are employed in establishments that stay covered as the control group. A differencein-difference estimator based upon eq. (3) will consistently identify $\gamma_{C}$ only, if the expression

$$
E\left(\Delta \lambda_{j t} \mid \Delta C_{j t}=-1, \Delta x_{i t}, \Delta z_{j t}\right)-E\left(\Delta \lambda_{j t} \mid \Delta C_{j t}=0, \Delta x_{i t}, \Delta z_{j t}\right)
$$

equals zero, since otherwise we have

$$
\begin{aligned}
E\left(\Delta \ln w_{i t} \mid\right. & \left.\Delta C_{j t}=-1, \Delta x_{i t}, \Delta z_{j t}\right)-E\left(\Delta \ln w_{i t} \mid \Delta C_{j t}=0, \Delta x_{i t}, \Delta z_{j t}\right) \\
= & -\gamma_{C}+B I A S,
\end{aligned}
$$

where the $B I A S$ is given by eq. (5). ${ }^{7}$ If, for example, establishments leaving industry-level bargaining are suffering from more negative time trends than those that retain their contract status, the term in eq. (5) will be negative, thereby giving rise to a downward biased estimate of $-\gamma_{C}$. To adjust the estimator of $\gamma_{C}$ for this potential bias, we will attempt to match the term given by eq. (5) by estimating the differential in wage growth in the pre-transition periods, i.e. by

$$
E\left(\Delta \ln w_{i t-k} \mid \Delta C_{j t}=-1, \Delta x_{i t}, \Delta z_{j t}\right)-E\left(\Delta \ln w_{i t-k} \mid \Delta C_{j t}=0, \Delta x_{i t}, \Delta z_{j t}\right)
$$

Subtracting this expression from the (biased) difference-in-difference estimator for $\gamma_{C}$ will consistently identify $\gamma_{C}$, provided a similar macro-trend has occurred over the interval $t-k-1$ to $t-k$. At this point, it is worth noting that our data restrictions will not allow us to estimate the difference in time trends by using information from a longer pre-transition time interval, as most of our regime switchers cannot be tracked over a longer time period prior to the observed transitions. Given that we have to rely on wage growth in at most two pre-transition years (i.e. $k=2$ ), the

\footnotetext{
${ }^{7} \mathrm{~A}$ further assumption is conditional mean independence of $\Delta C_{j t}$ and $\Delta \varepsilon_{i t}$.
} 
question of whether the differential in wage growth reflects a difference in long-term trends or a mere anticipation effect is crucial to the correction of the bias as given by eq. (5). A difference in pre-transition wage growth in the sense of an Ashenfelter's dip (Blundell and Costa Dias 2002) would imply that the bias as given by eq. (5) should basically reverse its sign. However, the discussion in Section 2 has shown that the institutional impediments to changing contract status render such anticipation effects very unlikely. This is particularly true for those regime changes from existing contracts that are associated with lower wages in the pre-transition periods. The reason is that any regime switch that involves leaving an existing contract may be expected to come into effect after a certain time lag after the transition has taken place. For existing contracts, this implies that negative differences in pre-transition wage growth are difficult to reconcile with anticipation effects. ${ }^{8}$

\subsection{Data and Variable Description}

In the empirical analysis we use data from the IAB Linked Employer-Employee panel (LIAB) which combines data from the IAB-Establishment Panel and the Employment Statistics Register. The IAB-Establishment Panel is based on an annual survey of establishments in western Germany administered since 1993 by the research institute of the Federal Employment Services in Nuremberg. Establishments in eastern Germany entered the panel in 1996. The database is a representative sample of German establishments employing at least one employee who pays social security contributions. The survey collects a great deal of information on establishment structure and performance (see e.g. Bellmann et al. 2002).

The construction of the linked employer-employee data set occurs in two steps: First, we select establishments from the establishment panel data set. From the

\footnotetext{
${ }^{8}$ Note, however, that this argument does not apply to positive differences in pre-transition wage growth as firms are generally free to pay higher wages than those stipulated in the wage contract. In this case, we will evaluate the likelihood of a mere anticipation effect by looking at whether the difference in wage growth during the transition period reverses its sign. Such a development would argue against anticipation effects as the latter are likely to cause the observed larger pre-transition wage growth to be continued.
} 
available waves 1993 to 2008, we use the years 1995 to 2008, since detailed information on bargaining coverage is available only from 1995 onwards. Since information on a number of variables, such as investment expenditures and sales are gathered retrospectively for the preceding year, we lose information on the last year. In order to be able to conduct first-differencing, only establishments with consistent information on the variables of interest (described below) and at least two consecutive time-series observations are included in our sample. Moreover, we restrict our sample to establishments from the western German mining and manufacturing sector with at least two employees. We focus on these sectors for two reasons: First, unions are generally believed to be particularly strong in this part of the economy (Hassel 1999, Addison et al. 2007) and second, former studies have already established significant wage premiums associated with collective bargaining contracts in these sectors (Stephan and Gerlach 2005). We confine our analysis to western Germany as we argue that the endogeneity problem is likely to be somewhat smaller than in eastern Germany. The reason is that in western Germany unionisation is likely to be more exogenous, since it presumably reflects to a larger extent the result of a historically grown industrial relations structure as compared with eastern Germany. ${ }^{9}$ Overall, this sample selection results in a sample of 1,724 establishments with 7,589 observations, yielding an unbalanced panel containing establishment observations with, on average, 4.4 years of data.

As to collective bargaining coverage, establishments are asked to report whether they are bound to a centralised industry-wide collective wage agreement $(C)$ or, alternatively, to a firm-specific wage agreement $(F)$. Moreover, since 1999 establishments without any binding collective contract $(N)$ are asked whether they follow informally the terms of an industry-wide agreement. However, for the available waves respondents are not asked to provide any information on the precise nature of the voluntarily applied contract terms. As a result, the informational content of

\footnotetext{
${ }^{9}$ After German unification the western German system of collective bargaining had been set up quite immediately by western unions in eastern Germany. The decline in membership rates in eastern Germany then arose primarily from a rapid wage convergence between western and eastern Germany which unions succeeded to achieve following German unification (Hunt 2001).
} 
this question remains rather elusive. Throughout the following analysis, collective bargaining status therefore refers to the existence of a legally binding agreement, i.e. establishments informally following the terms of an industry agreement will be treated as being uncovered. As a consequence, our estimated wage premiums need to be interpreted as wage mark-ups associated with a legally binding collective wage agreement.

To avoid measuring spurious changes in contract status, we exploit the fact that employers face two legal impediments to leaving wage bargaining as set out in Section 2: The first one relates to the validity time limit according to which the contract terms continue to apply until the respective contract has expired, whereas the second one is due to the fact that employers are obliged to replace the contract terms by individual contracts in order to be able to depart from previous contractual arrangements. It is reasonable to believe that such a replacement will take place after a certain time lag and is likely to occur only if non-coverage is maintained for a sufficient amount of time. For this reason, we argue that employers who report a change from industry/firm-level coverage to no coverage and then an immediate change to either industry or firm-level coverage are very unlikely to have replaced the original contract terms by individual contracts. As a consequence, we impute all reported $F N F$ and $C N C$ sequences by $F F F$ and $C C C$ sequences, respectively. In our sample this affects 9 and 54 out of 1,724 establishments. In a similar vein, $F N C$ and $C N F$ sequences are substituted by $F F C$ and $C C F$, which affects 15 and 7 establishments, respectively. Moreover, for those plants with at least 4 time-series observations, who report the same regime for all time periods but one, we further impute the reported outlier-regime by the remaining regimes - in our sample this affects 50 establishments. From the remaining establishments, we exclude those that change their collective bargaining status more than once in the time-period under consideration. This affects 82 out of 335 establishments that still exhibit a variation in contract status. In section 3.3.5, we will conduct some robustness checks with respect to this exclusion and our adopted imputation procedure. 
In the second step, we merge the establishment data with individual-level information. The worker information comes from the Employment Statistics Register, which is an administrative panel data set based on notifications which employers are obliged to provide for each employee covered by the German social security system (see e.g. Bender et al. 2000). We merge the establishment data with notifications for all employees who are employed by the selected establishments on June $30^{\text {th }}$ of each year. From the worker data we drop observations for apprentices, part time workers and homeworkers. ${ }^{10}$ To avoid modeling human capital formation and retirement decisions, we exclude individuals younger than 19 and older than 55. Moreover, since we consider only full-time workers, we eliminate those workers whose wages fall short of some threshold level. ${ }^{11}$ Due to the very low proportion of movers, we exclude those individuals who move between sample establishments during the time period of consideration. Again, we consider only those individuals for whom at least two consecutive time-series observations are available. The final sample comprises 629,635 individuals in 1,613 establishments, yielding an unbalanced panel containing 2,714,750 individual observations with, on average, 4.3 years of data for each worker. ${ }^{12}$

The individual data include information on the gross daily wage, age, gender, nationality, employment status (blue/white-collar), educational status (three categories $)^{13}$ and on individual tenure, which has been adjusted for employment interruptions at the same employer. The dependent variable in the subsequent analysis is the real gross daily wage, which is reported inclusive of fringe-benefits as long as such wage supplements are subject to social security contributions. Since there is an upper contribution limit to the social security system, gross daily wages are

\footnotetext{
${ }^{10}$ Part time workers are excluded because the Employment Statistics Register lacks explicit information on hours worked.

${ }^{11}$ The threshold is defined as the twice amount of the lower social security contribution limit.

${ }^{12}$ Note that we lose some further establishments due to the exclusion of movers and those workerfirm combinations with less than two consecutive time-series observations.

${ }^{13}$ The categories are: Low-skilled (no vocational degree), medium-skilled (completed vocational degree), high-skilled (technical college degree or university degree). Missing and inconsistent data on education are corrected according to the imputation procedure described in Fitzenberger et al. (2006). This procedure relies, roughly speaking, on the assumption that individuals cannot lose their educational degrees.
} 
top-coded. In our sample, top-coding affects about 15 per cent of all observations. To address this problem, we construct 52 cells based on two education categories ${ }^{14}$, gender and year. For each cell, a Tobit regression is estimated with log daily wages as the dependent variable and individual and establishment covariates as explanatory variables. As described in Gartner (2005), right-censored observations are replaced by wages randomly drawn from a truncated normal distribution whose moments are constructed by the predicted values from the Tobit regressions and whose (lower) truncation point is given by the contribution limit to the social security system. After this imputation procedure, nominal wages are deflated by the Consumer Price Index of the Federal Statistical Office Germany normalised to 1 in 2000.

Turning to the establishment variables, we control for establishment size, percapita value added, the capital-labour ratio, the existence of a works council as well as collective bargaining coverage. ${ }^{15}$ Table 1 reports (non-weighted) sample statistics for individuals subject to an industry-level contract, a firm-level contract and for those without any bargaining coverage. The figures reveal that firm-level contracts are associated with the largest raw wage differential and the lowest variability in wages. The sample means for the establishment variables show that workers subject to firm-level agreements are, on average, employed by larger, more capital-intensive and more productive firms, followed by those covered by an industry-wide agreement. Note that the results with respect to firm size are in line with what has been found earlier in the literature (e.g. Schnabel et al. 2006).

\footnotetext{
${ }^{14}$ The two categories are: Low-skilled and medium/high-skilled.

${ }^{15}$ A more detailed description of the construction of the establishment variables can be found in Table A1 in the Appendix.
} 


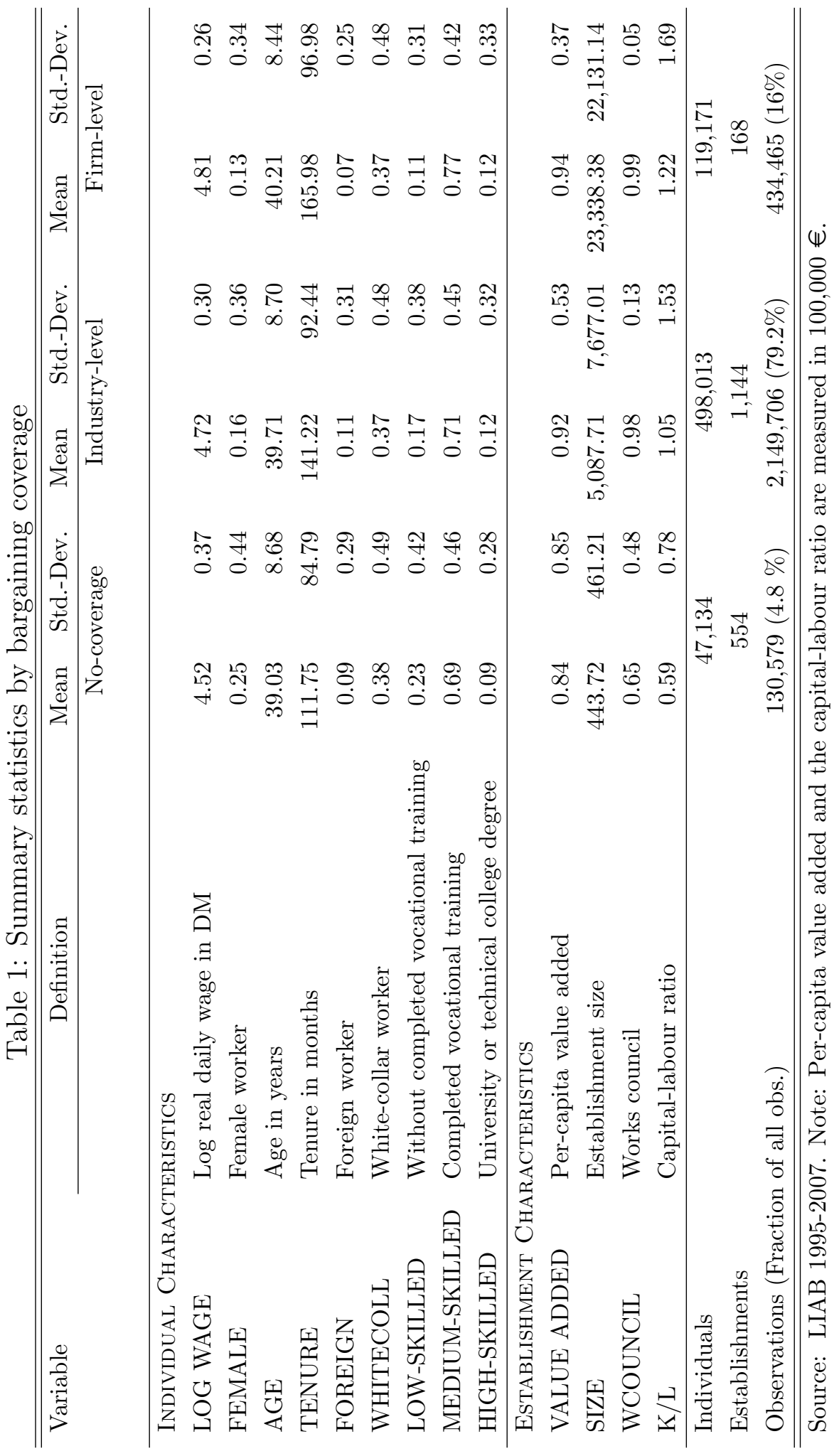


As to the individual characteristics, workers under firm and industry-specific contracts are, on average, more likely to be male, are less likely to have no vocational degree and have more months of tenure relative to uncovered individuals. As a result, most of the differences in observed establishment and individual characteristics would generally predict higher wages for workers in covered establishments, which clearly requires a multivariate estimation strategy.

Table 2: Regression results

\begin{tabular}{|c|c|c|c|c|c|c|}
\hline \multirow{3}{*}{ Region } & \multicolumn{2}{|l|}{ 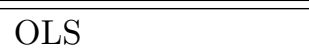 } & \multicolumn{2}{|c|}{ Plant fixed effects } & \multicolumn{2}{|c|}{ Spell fixed effects } \\
\hline & \multirow{2}{*}{\multicolumn{2}{|c|}{ (1) }} & \multirow{2}{*}{\multicolumn{2}{|c|}{ (2) }} & \multirow{2}{*}{\multicolumn{2}{|c|}{ (3) }} \\
\hline & & & & & & \\
\hline Variable & Coeff. & SE & Coeff. & SE & Coeff. & $\mathrm{SE}$ \\
\hline INDUSTRY-LEVEL & $0.060^{* * *}$ & $(0.010)$ & 0.006 & $(0.005)$ & 0.004 & $(0.003)$ \\
\hline FIRM-LEVEL & $0.055^{* * *}$ & $(0.018)$ & -.010 & $(0.008)$ & -.008 & $(0.006)$ \\
\hline FEMALE & $-.203^{* * *}$ & $(0.008)$ & $-.188^{* * *}$ & $(0.008)$ & - & - \\
\hline AGE & $0.022^{* * *}$ & $(0.001)$ & $0.022^{* * *}$ & $(0.001)$ & $0.033^{* * *}$ & $(0.008)$ \\
\hline $\mathrm{AGE}^{2}$ & $-.000^{* * *}$ & $(0.000)$ & $-.000^{* * *}$ & $(0.000)$ & $-.000^{* * *}$ & $(0.000)$ \\
\hline TENURE/10 & $0.007^{* * *}$ & $(0.001)$ & $0.008^{* * *}$ & $(0.001)$ & $0.017^{* * *}$ & $(0.006)$ \\
\hline$(\text { TENURE } / 10)^{2}$ & $-.000^{* * *}$ & $(0.000)$ & $-.000^{* * *}$ & $(0.000)$ & $-.000^{* * *}$ & $(0.000)$ \\
\hline FOREIGN & 0.003 & $(0.006)$ & -.008 & $(0.005)$ & - & - \\
\hline WHITECOLL $^{a)}$ & $0.293^{* * *}$ & $(0.006)$ & $0.282^{* * *}$ & $(0.006)$ & $0.053^{* * *}$ & $(0.010)$ \\
\hline MEDIUM-SKILLED ${ }^{b}$ & $0.076^{* * *}$ & $(0.004)$ & $0.068^{* * *}$ & $(0.003)$ & $0.063^{* * *}$ & $(0.009)$ \\
\hline HIGH-SKILLED & $0.243^{* * *}$ & $(0.010)$ & $0.234^{* * *}$ & $(0.007)$ & $0.116^{* * *}$ & $(0.017)$ \\
\hline$\overline{\log (\mathrm{SIZE})}$ & $0.028^{* * *}$ & $(0.004)$ & $0.018^{*}$ & $(0.011)$ & $0.030^{* *}$ & $(0.013)$ \\
\hline VALUE-ADDED & $0.033^{* * *}$ & $(0.006)$ & $0.010^{* *}$ & $(0.004)$ & -.001 & $(0.006)$ \\
\hline WCOUNCIL & $0.060^{* * *}$ & $(0.013)$ & 0.009 & $(0.006)$ & $0.014^{* *}$ & $(0.007)$ \\
\hline $\mathrm{K} / \mathrm{L}$ & $0.062^{* * *}$ & $(0.002)$ & $0.002^{* * *}$ & $(0.000)$ & 0.001 & $(0.002)$ \\
\hline
\end{tabular}

Source: LIAB 1995-2007. 1,613 establishments, 629,635 individuals, 2,714,750 (spell differenced: 2,063,951) observations. Note: The dependent variable is the individual log real daily wage. Standard errors are in parentheses and are adjusted for clustering at the establishment level. Model (1) includes 10 regional dummies and 16 industry dummies, model (3) includes no constant. All models include time dummies. ${ }^{a}$ Reference: Blue collar, b) Reference: Low-skilled. ${ }^{* * *}$ Significant at $1 \%$-level, ${ }^{* *} 5 \%$-level, ${ }^{*} 10 \%$-level. 


\subsection{Results}

\subsubsection{Pooled OLS Results}

From the descriptive statistics in Table 1 it can be seen that the raw wage differential amounts to about 20 log points under industry contracts and to 29 log points under firm-level contracts. Column (1) in Table 2 shows the results from estimating a pooled OLS (POLS) regressions controlling for a full set of individual and establishment characteristics. The figures show that with some minor exceptions all individual and establishment covariates enter the specifications with their expected sign and are significant at the $1 \%$-level. ${ }^{16}$ The estimates in Column (1) indicate that the wage premiums of both industry and firm-level contracts drop by about 70 and 80 per cent, respectively, once differences in individual and establishment characteristics are controlled for. Overall, the (unreported) results from stepwise POLS regressions indicate that observable establishment characteristics, such as differences in establishment size, per-capita value added and the capital-labour ratio, account for the largest proportion of omitted variable bias in the raw wage differentials.

\subsubsection{Unobserved Establishment Heterogeneity}

Given that establishment characteristics explain the largest proportion of the raw wage differentials, we next control for establishment fixed effects to assess the extent to which sorting of unobservably better employers into the regimes affects our estimates. With an establishment fixed effects specification, the wage premiums associated with firm and industry-level contracts are identified solely from withinestablishment variation in contract status. To gain an idea about the underlying dynamics with respect to collective bargaining status, Table 3 reports the number of observed transitions between the three regimes. ${ }^{17}$ Closer inspection of the

\footnotetext{
${ }^{16}$ In particular, establishment size, per-capita value added and the capital-labour ratio are found to be positively related to wages, a result which is consistent with what has been found earlier in the literature. For firm size effects see e.g. Oi and Idson (1999), German evidence on employer size effects is provided by Schmidt and Zimmermann (1991). Hildreth and Oswald (1997) and Arai (2003) present international evidence on the wage-profit relationship, while evidence for Germany is documented in Hübler and König (1998) and Guertzgen (2009).

${ }^{17}$ The number of individuals affected by each transition is reported in Table 5.
} 
off-diagonal entries in Table 3 shows that 253 out of 1,613 establishments (15.7 per cent) changed contract status between 1995 and 2007, with the biggest movement taking place between no-coverage and industry-level contracts. In addition, the figures indicate that the number of establishments becoming uncovered (119 "quitters") if found to exceed the number of establishments becoming covered (72 "joiners"). Column (2) in Table 2 shows the results from estimating a establishment fixed effects specification. ${ }^{18}$ While the coefficients on the individual covariates are quite similar to those from the OLS specifications, the coefficients on the plantlevel variables decline substantially for the majority of covariates. The coefficient on industry-level contracts becomes very small and insignificant, whereas the wage premium under firm-level contract is even negative. Overall, these findings indicate that the wage premiums essentially vanish once the non-random selection of firms into the bargaining regimes is accounted for. Note, however, that the establishment fixed effect may also reflect a positive selection on behalf of workers as long as $\phi_{j}$ reflects a time-constant unobservably better workforce composition.

Table 3: Changes in contract status

\begin{tabular}{lrrrr}
\hline \hline $\begin{array}{l}\text { Transitions } \\
\text { from }\end{array}$ & to: & Industry-level & Firm-level & No-coverage \\
\hline Industry-level & 920 & 37 & 100 & $1,057(65.5 \%)$ \\
Firm-level & 25 & 77 & 19 & $121(7.5 \%)$ \\
No-coverage & 62 & 10 & 363 & $435(27.0 \%)$ \\
\hline & $1,007(62.4 \%)$ & $124(7.7 \%)$ & $482(29.9 \%)$ & 1,613 \\
\hline \hline
\end{tabular}

Source: LIAB 1995-2007. The figures refer to the number of establishments.

\subsubsection{Unobserved Individual and Establishment Heterogeneity}

The estimated wage mark-ups might still be biased if a within-establishment variation of contract status were correlated with a change in the composition of workers' unobservable skills. To address this further source of bias, we next control for both individual and establishment-specific unobservables, $\alpha_{i}$ and $\phi_{j}$, by estimating a spell

\footnotetext{
${ }^{18}$ To avoid including 1,612 additional dummy variables, all variables are transformed by subtracting averages at the establishment level.
} 
differenced specification. Note that identification of both $\alpha_{i}$ and $\phi_{j}$ is driven by individuals who move between establishments within our sample. In the extreme case of no turnover between sample establishments, spell and individual fixed-effects yield the same results, and $\alpha_{i}$ and $\phi_{j}$ cannot be separately identified. A closer examination of the distribution of the number of spells shows that the majority of individuals do not move between sample establishments - only 0.9 per cent of all workers in the original sample move from one sample establishment to another. ${ }^{19}$ Moreover, out of 615 establishments with sample movers, 433 (about 70 per cent) employ less than 5 movers (out of which 221 have only one single mover). We therefore excluded movers from our sample and do not separately identify $\alpha_{i}$ and $\phi_{j}$ as proposed by Abowd et al. (1999), since for a large number of firms such an identification would have to rely on a very small number of movers to estimate the establishment effect. ${ }^{20}$ Column (3) of Table 2 reports the results from the spell fixed effects specifications. Since first differencing involves the loss of at least one wave for each worker, the number of observations drops to $2,063,951 .^{21}$ The figures show that spell differencing does not alter the estimates of the wage premiums substantially. Overall, these results suggest that establishments changing contract status do not experience a simultaneous change in the unobservable skill composition of their workforce. Note that this contrasts with other establishment covariates, such as value added and the capital-labour ratio, whose coefficients are estimated to be smaller once changes in the composition of workers' unobservable skills are accounted for.

As mentioned earlier, much of the empirical research on union wage effects sug-

\footnotetext{
${ }^{19}$ The low proportion of movers is due to the fact that the linked employer-employee data set is based on a sample of establishments. As a result, the probability of observing workers moving from one sample establishment to another is very low. It is important to note that the low proportion of movers does not imply that our data set is restricted to very stable employment relationships as workers (and firms) may enter and exit the panel.

${ }^{20}$ The descriptive statistics of the spell differenced variables are displayed in Table A2 in the appendix. For the majority of covariates, the figures indicate a considerable dispersion of the differenced values over time. Exceptions are the skill dummies, where only a very small fraction of workers experience a change in these variables. It is worth noting that these changes are unlikely to reflect pure measurement error, as we adopted an imputation procedure to correct misreporting of the education variable (see Section 3.2).

${ }^{21}$ Note, however, that the resulting number of observations after spell differencing is smaller than the number of total individual observations minus the number of individuals, as the sample includes workers with intermittent panel participation.
} 
gests that unions do not only affect the mean but also the overall dispersion of wages through their impact on the returns to worker and firm attributes. To assess the im-

Table 4: Interacted spell differenced regression results

\begin{tabular}{|c|c|c|c|c|c|c|}
\hline \multirow{3}{*}{$\begin{array}{l}\text { Regime } \\
\text { Region }\end{array}$} & \multicolumn{2}{|c|}{ No-coverage } & \multicolumn{2}{|c|}{ Industry-level } & \multicolumn{2}{|c|}{ Firm-level } \\
\hline & \multirow{2}{*}{\multicolumn{2}{|c|}{ (1) }} & \multirow{2}{*}{\multicolumn{2}{|c|}{ (2) }} & \multirow{2}{*}{\multicolumn{2}{|c|}{ (3) }} \\
\hline & & & & & & \\
\hline & & & \multicolumn{4}{|c|}{ WAGE PREMIUMS } \\
\hline \multirow{3}{*}{ Variable } & & & $0.015^{* *}$ & $(0.006)$ & -.003 & $(0.015)$ \\
\hline & \multirow{2}{*}{\multicolumn{6}{|c|}{$\begin{array}{r}\text { Returns to Individual CharaCteristics } \\
\text { (InTERACTION EFFECTS) }\end{array}$}} \\
\hline & & & & & & \\
\hline$\triangle$ FEMALE & - & - & -.002 & $(0.003)$ & 0.007 & $(0.005)$ \\
\hline$\triangle \mathrm{AGE}$ & $0.035^{* * *}$ & $(0.008)$ & 0.000 & $(0.001)$ & -.001 & $(0.002)$ \\
\hline$\triangle \mathrm{AGE}^{2}$ & $-.000^{* * *}$ & $(0.000)$ & -.000 & $(0.000)$ & 0.000 & $(0.000)$ \\
\hline$\Delta$ TENURE/10 & $0.010^{* * *}$ & $(0.000)$ & $0.002^{* * *}$ & $(0.000)$ & $0.002^{*}$ & $(0.001)$ \\
\hline$\Delta(\text { TENURE } / 10)^{2}$ & $-.000^{* * *}$ & $(0.000)$ & $-.000^{* * *}$ & $(0.000)$ & $-.000^{*}$ & $(0.000)$ \\
\hline$\triangle$ FOREIGN & - & - & $-.008^{*}$ & $(0.006)$ & -.008 & $(0.007)$ \\
\hline$\Delta$ WHITECOLL & $0.054^{* * *}$ & $(0.009)$ & -.000 & $(0.004)$ & -.009 & $(0.008)$ \\
\hline$\triangle$ MEDIUM-SKILLED & $0.045^{* * *}$ & $(0.010)$ & 0.003 & $(0.004)$ & $0.026^{* * *}$ & $(0.008)$ \\
\hline \multirow[t]{3}{*}{$\Delta$ HIGH-SKILLED } & $0.093^{* * *}$ & $(0.019)$ & 0.007 & $(0.006)$ & $0.036^{* * *}$ & $(0.011)$ \\
\hline & \multirow{2}{*}{\multicolumn{6}{|c|}{$\begin{array}{l}\text { Returns to Establishment CHARACTERISTICs } \\
\text { (InTERACTION EFFECTS) }\end{array}$}} \\
\hline & & & & & & \\
\hline$\Delta \log (\mathrm{SIZE})$ & $0.024^{* *}$ & $(0.010)$ & 0.004 & $(0.003)$ & 0.001 & $(0.008)$ \\
\hline$\triangle$ VALUE ADDED & $0.009^{* * *}$ & $(0.001)$ & -.005 & $(0.005)$ & $-.005^{* *}$ & $(0.002)$ \\
\hline$\triangle$ WCOUNCIL & $0.012^{* *}$ & $(0.006)$ & 0.002 & $(0.006)$ & 0.012 & $(0.011)$ \\
\hline$\Delta \mathrm{K} / \mathrm{L}$ & -.000 & $(0.000)$ & 0.004 & $(0.003)$ & 0.000 & $(0.000)$ \\
\hline
\end{tabular}

Source: LIAB 1995-2007. 1,613 establishments, 629,635 individuals, 2,063,951 observations.

Note: The dependent variable is the spell differenced individual log real daily wage. Standard errors are in parentheses and are adjusted for clustering at the establishment level. The model includes no constant and 11 time dummies.

${ }^{* * *}$ Significant at $1 \%$-level, ${ }^{* *} 5 \%$-level, ${ }^{*} 10 \%$-level.

pact of collective bargaining coverage on the overall wage structure, Table 4 reports the estimates of a fully interacted spell differenced specification, which includes interaction terms of all covariates with the contract status dummies. The average wage premiums for firm and industry-level contracts are presented in the first row of Columns (2) and (3), respectively, whereas the interaction effects of individual and establishment level observables are shown below. Recall that the interacted 
regressors are expressed in terms of deviations from their sample means, so that the estimated coefficient on firm and industry-level contracts is to be interpreted as the wage premium for a worker with the average characteristics of the sample. The results from the interacted spell differenced regressions imply a wage mark-up of about 0.015 under industry-level contracts, which is statistically significant. The estimated wage premium under firm-level contracts is close to zero (-0.003) and is very imprecisely estimated. Groupwise $F$-tests testing the joint significance of the interaction coefficients for industry and firm-level contracts reject the null-hypothesis of the equality of all the coefficients across the three regimes (with $p$-values below $0.001)$.

The estimated interaction effects in Table 4 show that the estimated returns to most of the individual attributes are not significantly smaller for covered individuals. The returns to tenure are larger under both firm and industry level contracts. Moreover, firm-level contracts are found to significantly increase the returns to medium and high-skilled qualifications. Note that these findings stand in contrast to what is typically obtained by a simple interacted POLS regression, suggesting that collective contracts reduce the returns to observable worker attributes. ${ }^{22}$ This pattern of results is consistent with the notion that the typical flattening of the wage structure that emerges from a simple POLS specification arises from a selectivity bias, since workers with low levels of observed skills tend to be positively selected and workers with higher levels of observed skills tend to be negatively selected into covered firms. To highlight this selection process, it may be instructive to compare, for example, the firm-level wage premium among workers without any vocational degree to the premium among high-skilled workers (with a technical college or university degree). For the latter, the wage premium resulting from an (unreported) interacted POLS specification is $-4.7 \log$ points and increases to 1 log points in the spell differenced specification. By comparison, for a worker without any degree the interacted POLS

\footnotetext{
${ }^{22}$ The results from an (unreported) fully interacted POLS specification indicate that the estimated returns to most of the individual attributes such as age, gender, tenure and a medium and high-skilled qualification are smaller for covered individuals. The established flattening of the wage structure is similar to what has been found in the international literature and confirms recent findings by Stephan and Gerlach (2005) for Germany.
} 
specification implies a positive wage premium of $3.5 \log$ points, which drops to about $-2.6 \log$ points once the selection into the regimes is accounted for. As a result, the estimates of the equalising effect of firm-level contracts on low-skilled workers from the POLS specification considerably overstate the true equalising effect and may even reverse the premiums across skills. As to the returns to establishment attributes, the estimates show that the returns to plant size are larger under industry-level contracts, even though the coefficient on the interaction term only borders significance (with a $p$-value of 0.12 ). Moreover, both firm and industry-level contracts are found to decrease the returns to establishment productivity, even though the interaction term under industry-level contracts is fairly imprecisely estimated.

\subsubsection{Analysing Separate Transitions}

Even though the spell differenced specifications conditioned on an important set of establishment characteristics such as changes in establishment size, capital intensity and productivity, a change in contract status might still be correlated with time-specific unobservables. To assess the severity and direction of a potential endogeneity bias, we now present the estimation results based on a trend-adjusted difference-in-difference approach. To do so, we separately analyse transitions from one regime to the other by contrasting the wage growth of individuals experiencing a change in contract status to the wage growth of those individuals who are employed by plants that stay in the origin regime. As set out in section 3.1, the resulting estimator is adjusted for differences in changes in time-specific shocks by subtracting the differential in wage growth in the pre-transition periods. Due to a change in the survey question in 1998, the analysis of separate transitions will be confined to the period 1999 to $2007 .{ }^{23}$ To gain further insights into potential sources

\footnotetext{
${ }^{23}$ For the transitions prior to 1999 , an important concern is that a change in the survey question between 1997 and 1998 might have induced an incorrect reporting of the existence of firm-level contracts until 1998. Until 1998, the survey question concerning firm-level contracts was "In this establishment, is there a firm-level contract in force?" and changed afterwards to "... is there a firm-level contract in force that has been concluded between this establishment and a trade union?" (author's translation). Arguably, this may have induced an incorrect reporting of firmlevel contracts particularly among those establishments who had concluded a plant-level agreement with their works council.
} 
of different time-specific shocks, Table A3 in the appendix presents characteristics of switching establishments compared with those in the reference groups. Closer inspection of differences in observable characteristics may give us some further indication about the severity of a potential endogeneity bias as it seems reasonable to assume that differences in unobservable factors are likely to be correlated with differences in observables. In Table 5, each panel's first row presents the estimates of the wage premium of a particular transition. The third column contains the estimated wage premium in the transition period $t$. This wage premium is based on the pooled estimation of eq. (4) on the subsample of plants that experience a change in contract status in $t$ ("regime switchers") and those plants that always adopt the origin regime ("stable plants"). For those employers and workers for whom sufficient time-series observations are available, the remaining columns contain the estimated differences in wage growth between regime switchers and stable plants in the pre and post-transition years $t-1, t-2, t+1$ and $t+2$, respectively. These estimates are again based on the pooled estimations of eq. (4) for the respective time periods on the subsample of regime switchers and stable plants. ${ }^{24}$ Finally, each panel's second (third) row presents the trend-adjusted wage premiums which result from the differences between the estimated wage premiums in $t, t+1$ and $t+2$ and the pre-transition differentials in wage growth in $t-1(t-2)$.

Turning first to the transitions from industry to firm-level contracts, Table 5 reports a significantly negative wage premium of $-3.1 \log$ points in period $t$. The wage premium in $t+1$ is of similar magnitude. The estimated difference in pretransition wage growth in $t-1$ is found to be positive and significant, indicating that wages for these regime changers did rise relatively stronger prior to the transition year. ${ }^{25}$ With respect to the pre-transition differentials in wage growth in $t-1$, this

\footnotetext{
${ }^{24}$ This amounts to estimating eq. (4) including the respective lags and leads of a dummy variable that indicates the change in contract status in $t$. To estimate the pre and post-transition wage growth differentials, we include all individuals in the respective time periods, i.e. also those who are not employed by the regime switchers in period $t$. We further exclude from these individuals those who are also subject to a change in contract status in $t-1, t-2, t+1$ and $t+2$, respectively.

${ }^{25}$ Note that the discussion in Section 3.1 has shown that positive differences in pre-transition wage growth may not rule out mere anticipation effects as firms are generally free to pay higher
} 
Table 5: Analysis of separate transitions

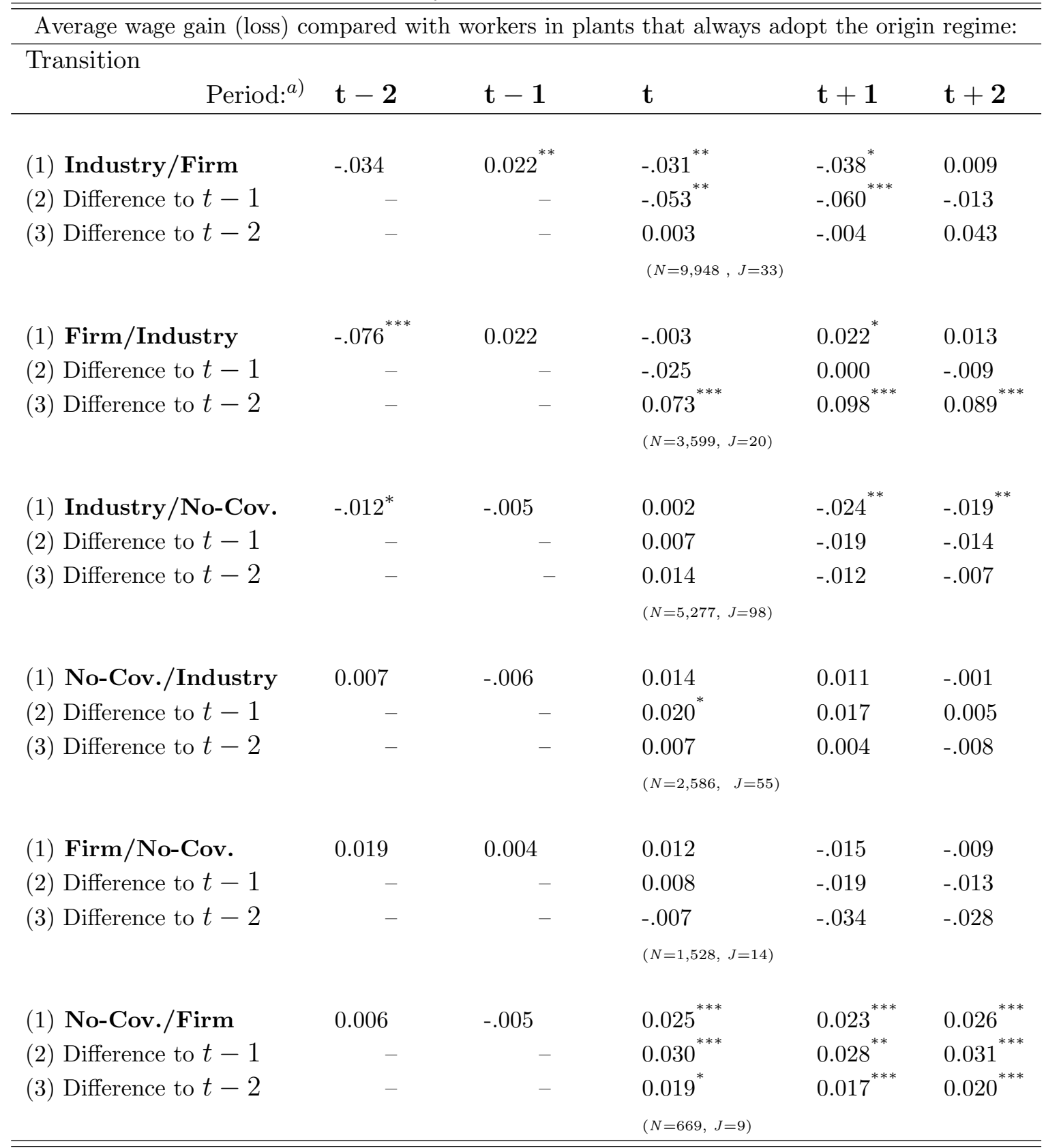

Source: LIAB 1999-2007. The estimates of the wage premiums are obtained by estimating the interacted spell differenced specification using the respective subsamples of establishments (those that experience the change in contract status and those that retain the origin regime). Standard errors are adjusted for clustering at the establishment-level. $J$ refers to the number of establishments and $N$ refers to the number of individuals experiencing the transitions.

a) $t$ refers to the year of the transition. A transition in year $t$ is defined as a change in contract status between year $t-1$ and $t .{ }^{* * *}$ Significant at $1 \%-,{ }^{* *} 5 \%-,{ }^{*} 10 \%$-level. 
gives rise to significantly negative wage premiums of firm-level contracts in $t$ and $t+1$.

In the next panel, the estimate for the wage premium in $t$ indicates that individuals subject to a change from firm to industry-level contracts experience no significant wage change relative to those individuals in stable plants. This contrasts with the wage premiums for the subsequent time periods $t+1$ and $t+2$, which are estimated to be positive. However, the descriptive statistics in Panel $\mathrm{C}$ in Table A3 in the appendix indicate that these estimates might still be downward biased, as establishments joining industry-level contracts are considerably smaller and less capital-intensive than those that are always covered by firm-level contracts. While the notion that "joiners" of industry-level contracts might have experienced different time-specific shocks is not supported by the differences in pre-transition wage growth in $t-1$, it is confirmed by the significantly negative difference in wage growth in $t-2$. This gives rise to trend-adjusted positive estimates for $\gamma_{C}$, whose coefficients are found to be highly significant in period $t, t+1$ and $t+2$.

The next panel in Table 5 shows the results for the transitions from industrylevel bargaining to no-coverage. The estimate for the wage premium in $t$ indicates that individuals in leaving plants experience no immediate significant wage change relative to those individuals who are always covered by industry-level contracts. However, workers in leaving plants incur a significant relative wage loss one and two years after the transition, indicating that wage adjustments after contract status change may take some time (see the estimates for $t+1$ and $t+2$ ). As set out in section 3.1, for establishments leaving industry-level contracts one might expect a downward biased estimate of the overall wage premium (corresponding to an upward bias of the industry-level contract wage premium relative to uncovered plants). The underlying notion is that the decision to leave industry-level bargaining is likely to be correlated with negative shocks. The estimates in row (2) indicate that this

wages than those stipulated in the wage contract. However, our results for the industry to firmlevel transitions show that the larger pre-transition wage growth among the regime switchers is not found to continue in the transition period and is therefore unlikely to reflect anticipation effects. 
expectation is borne out by the estimates, as the negative wage premiums become smaller and insignificant once negative pre-transition differences in wage growth are accounted for. Note that the evidence of a downward biased estimate is further confirmed by differences in observables in Panel B in Table A3. The figures show that leaving plants differ considerably in firm size, productivity and capital intensity from stable plants, with all differences being statistically significant.

Analysing the transitions from no-coverage to industry-level contracts, the estimates for the transition period $t$ indicate that individuals joining industry-level contracts experience a positive wage mark-up of the magnitude of $1.4 \mathrm{log}$ points (bordering significance with a $p$-value of 0.11 ). The fact that joining industry-level contracts from no-coverage as well as from firm-level contracts may entail a positive wage mark-up raises the question why employers join industry-level bargaining if doing so is voluntary in Germany. One possible explanation relates to the potential of workers to present employers with a credible threat to strike. Unfortunately, the differences in observables shown in Panels $\mathrm{A}$ and $\mathrm{C}$ in Table A3 do not give a clue regarding these potential explanations: Neither do switching employers have a larger fraction of works councils than stable plants nor do they exhibit any systematic differences in the workforce composition which might help explain a larger propensity of union organisation. The only differences that stand out are that establishments joining industry-level contracts have a somewhat larger fraction of blue-collar workers than those always staying uncovered. An alternative explanation might be that the decision to join industry-level contracts is driven by others factors. For instance, employers might favour industry-level contracts as standardised wage agreements save transaction costs that typically arise when stipulating individual or firm-specific contracts.

The transitions from firm-level contracts to no-coverage show that workers in leaving plants experience a relative wage loss of 1.5 and 0.9 log points one and two years after the transition. However, these wage premiums are very imprecisely estimated. Even though workers in leaving plants tend to experience a larger wage 
growth prior to the transitions, the negative trend-adjusted wage premiums are also insignificant. Turning next to employers joining firm-level contracts from nocoverage, the estimates clearly indicate that workers in joining plants incur positive and significant wage premiums that last for at least two further years. Even though the differences in observables in Panel A in Table A3 show that joining plants appear to be larger and more capital intensive than those always staying uncovered, the insignificant differences in pre-transition wage growth across regime switchers and stable plants do not provide evidence of a potential endogeneity bias. The descriptives further suggest that joining plants have significantly more often a works council than those always staying uncovered. This indicates that, other than for industry-level contracts, works councils might be an import means to enforce firmlevel contracts. Note that this finding is consistent with firm-level contracts being strongly determined by firm-specific union organisation, as a large majority of works councilors are generally recruited from union members. Overall, however, we wish to note that these estimates are to be interpreted with particular caution as they are based on a very small number of establishments joining firm-level contracts.

Taken together, the analysis of separate transitions suggests that the insignificant wage premiums of firm-level contracts that have been obtained from the pooled spell differenced regressions mask substantial heterogeneity across the different transitions. While joining firm-level bargaining from no-coverage may well be associated with a positive wage premium, the transitions between firm and industry-level contracts tend to give rise to negative wage premiums of firm-level contracts. At this point it is instructive to compare the industry to firm-level with the industry-level to no-coverage transitions. The result that both transitions result in an immediate or lagged wage loss may be interpreted as evidence that these regime switches appear to be initiated by employers. What determines whether employers leaving industry-level bargaining switch to firm-level bargaining or completely withdraw from bargaining? The trend-adjusted difference-in-difference estimates show that the transitions to no-coverage are associated with less pre-transition wage growth, whereas the transitions to firm-level contracts tend to be associated with larger 
pre-transition wage growth as compared with the reference group. These different patterns of pre-transition wage growth suggest that unions succeed in maintaining unionisation by firm-level contracts only in successful firms. This notion is further supported by the differences in observables in Panel B in Table A3, which suggest that plants switching from industry to firm-level contracts are no less productive than stable plants. The descriptives further support the view that local worker representations might help maintain unionisation. The reason is that employers switching to firm-level contracts have significantly more frequently a works council than those withdrawing from collective bargaining. Taken together, our findings argue against the view that the transition from industry to firm-level contracts is initiated by unions in order to secure even higher wages as compared with those stipulated in the respective industry-level agreements. The results rather suggest that firm-level contracts are the only means left to maintain unionisation at employers who otherwise would have become non-unionised.

\subsubsection{Robustness Checks}

In this section, we assess the sensitivity of our findings with respect to our imputation procedure. To do so, we reestimated the wage premiums associated with the separate regime switches using the raw transitions. In the original sample, we observe 617 transitions as compared to 253 transitions reported in Table $3 .{ }^{26}$ Overall, the pattern of results is similar to that in Table 5, even though the transitions between industrylevel contracts and no-coverage are estimated with less precision. Note that this is consistent with the estimates being biased towards zero due to some employers misreporting contract status changes. A major exception that stands out are the transitions from no-coverage to firm-level contracts. Contrary to what has been found earlier, the wage premium is negative in $t$ and becomes significantly positive only with some time lag in $t+1$ and $t+2$. Thus, the positive wage premiums found earlier appear to be particularly sensitive to the adopted imputation and exclusion of

\footnotetext{
${ }^{26}$ The results of the following robustness checks corresponding to those in Tables 5 can be found inTable A4 and A5 in the Appendix.
} 
plants with many contract status changes. Note that the established negative wage premium after including plants reporting several back and forth regime switches suggests that the latter are likely to be particularly negatively selected.

\section{Summary and Conclusions}

Using a large linked employer-employee data set from western German manufacturing, this paper has provided new evidence on collective bargaining wage premiums. By using longitudinal data, we seek to improve on recent evidence which relies on cross-sectional data to estimate the collective bargaining premium. Summing up, our results indicate that between 70 and 80 per cent of the wage premium associated with industry and firm-level contracts can be explained by differences in observables. Overall, the results suggest that differences in firm characteristics account for the largest proportion of omitted variable bias.

Taken together, the pooled differenced specifications suggest the following conclusions. First, differences in observables and unobservables nearly explain the full firm and industry-level contract wage premium. In failing to detect substantial wage premiums relative to uncovered firms, our findings seem to be in line with the results reported by Hartog et al. (2002), who find no evidence of substantial industry and firm-level contract wage premiums for the Netherlands. The authors interpret this result as a consequence of the relatively corporatist Dutch wage determination system. Note that a similar conclusion might apply to Germany, where centralised unions are likely to internalise negative externalities resulting from their wage demands. A further possible explanation might be that our identification strategy cannot rule out the possibility that the small estimated wage premiums may be an artefact of formal contract changes that are not paralleled by changes in actual wage policies. For example, the small estimated wage mark-ups might be driven by the fact that those establishments joining industry-level contracts already informally followed the terms of such contracts (or, alternatively, that those who formally leave industry-level bargaining continue to apply the contract terms). Particularly for 
the transitions that involve leaving industry-level contracts we are able to rule out such an explanation. The results suggest that workers in firms leaving industrylevel bargaining may incur wage losses relative to those workers who are employed by "stable" firms. However, adjusting the estimates for differential time trends supports the notion that plants changing from industry-level contracts to no coverage experience more negative time-specific shocks than stable plants, thereby confirming the result that there is no "true" wage effect of leaving wage bargaining.

For firm-level contracts, the analysis of separate transitions suggests that the overall insignificant wage premiums that have been obtained from the pooled differenced regressions mask substantial heterogeneity across the different transitions. The separate transitions indicate that joining firm-level bargaining from no-coverage may well be associated with a positive wage premium, whereas the transitions between firm and industry-level contracts tend to give rise to negative wage premiums of firm-level contracts. This finding is consistent with firm-level bargaining being initiated by employers who were formerly covered by an industry-level contract and argues against the view that unions tend to enforce such contracts in order to secure above average wage gains in highly successful firms.

Finally, there are several potential directions for future research. First, we have focused on the association between a change in contract status and wages. Future research should address the question as to how other outcomes such as employment and investment decisions are affected by collective bargaining coverage. Second, our analysis was confined to two years after the change in contract status. As the legal impediments to a change in contract status suggest that wage adjustments may take some time, further investigations should go into the long-run effects in order to explore whether there are further dynamics in the response of wages. This requires the availability of a considerably longer panel data set, which would allow a sufficiently large number of establishments changing contract status to be tracked over a longer time period. 


\section{References}

[1] Abowd, J. M., Kramarz, F. and D. N. Margolis (1999), High-wage workers and high-wage firms, Econometrica 67, 251-333.

[2] Addison, J., Schnabel, C. and J. Wagner (2007), The (parlous) state of German unions, Journal of Labor Research 28, 3-18.

[3] Agell, J. and K. Lommerud (1992), Union egalitarianism as income insurance, Economica 59, 295-310.

[4] Andrews, M. J., Stewart, M. B., Swaffield, J. K. and R. Upward (1998), The estimation of union wage differentials and the impact of methodological choices, Labour Economics 5, 449-474.

[5] Andrews, M. J., Schank, T. and R. Upward (2006), Practical fixed effects estimation methods for the three-way error components model, The Stata Journal 2006, 461-481.

[6] Arai, M. (2003), Wages, profits and capital-intensity: evidence from matched worker-firm data, Journal of Labor Economics 21, 593-618.

[7] Bell, B., Blundell, R. and J. van Reenen (1999), Getting the unemployed back to work: an evaluation of the new deal proposals, International Tax and Public Finance 6, 339-360.

[8] Bellmann, L., Kohaut, S. and M. Lahner (2002), Das IAB-Betriebspanel Ansatz und Analysepotenziale, in: Kleinhenz, G. (ed.), IAB-Kompendium Arbeitsmarkt- und Berufsforschung, Beiträge zur Arbeitsmarkt- und Berufsforschung 250, 13-20, Nürnberg.

[9] Bender, S. , A. Haas and C. Klose (2000), IAB-Employment Subsample 19751995. Opportunities for analysis provided by the anonymised subsample, IZA Discussion Paper No. 117. Bonn.

[10] Blanchflower, D. G. and A. Bryson (2010), The wage impact of trade unions in the UK public and private sectors, Economica 77, 92-109.

[11] Blundell, R. and M. Costa Dias (2002), Alternative approaches to evaluation in empirical microeconomics, Portuguese Economic Journal 1, 91-115.

[12] Calmfors, L. and J. Driffill (1988), Centralization of wage bargaining, Economic Policy 6, 12-61.

[13] Calmfors, L. (2001), Wages and wage-bargaining institutions in the EMU - a survey of the issues, Empirica 28, 325-351.

[14] Card, D. (1996), The effect of unions on the structure of wages: A longitudinal analysis, Econometrica 64, 957-979. 
[15] Card, D. and S. de la Rica (2006), Firm-level contracts and the structure of wages in Spain, Industrial and Labor Relations Review 59, 573-592.

[16] Cardoso, A. R. and P. Portugal (2005), Contractual wages and the wage cushion under different bargaining settings, Journal of Labor Economics 23, 875-902.

[17] DiNardo, J. and D. S. Lee (2004), Economic impacts of new unionization on private sector employers: 1984-2001, The Quarterly Journal of Economics 119, 1383-1440.

[18] Ellguth, P. and S. Kohaut (2008), Tarifbindung und betriebliche Interessenvertretung: Ergebnisse aus dem IAB-Betriebspanel 2007, WSI-Mitteilungen 9/2008.

[19] Farber, H. (1983), The determination of the union status of workers, Econometrica 51, 1417-1437.

[20] Fitzenberger, B., Osikominu, A. and R. Völter (2006), Imputation rules to improve the education variable in the IAB Employment Subsample, Schmollers Jahrbuch 126, 405-436.

[21] Fitzenberger, B., Kohn, K. and A. Lembcke (2008), Union density and varieties of coverage: The anatomy of union wage effects in Germany, ZEW-DiscussionPaper 08-012. Mannheim. Forthcoming: Industrial and Labor Relations Review.

[22] Freeman, R. B. (1984), Longitudinal analyses of the effects of trade unions, Journal of Labor Economics 2, 1-26.

[23] Gartner, H. (2005), The imputation of wages above the contribution limit with the German IAB employment sample. FDZ Methodenreport Nr. 02/2005, Nürnberg.

[24] Gesamtmetall (2012), Daten in Zeitreihen, http://www.gesamtmetall.de.

[25] Guertzgen, N. (2009), Rent-sharing and collective bargaining coverage - evidence from linked employer-employee data, Scandinavian Journal of Economics $111,289-315$.

[26] Hartog, J., Leuven, E. and C. Teulings (2002), Wages and the bargaining regime in a corporatist setting: the Netherlands, European Journal of Political Economy 18, 317-331.

[27] Hassel, A. (1999), The erosion of the German system of Industrial Relations, British Journal of Industrial Relations 37, 483-506.

[28] Hempell, T. (2005), What's spurious? What's real? Measuring the productivity impacts of ICT at the firm level, Empirical Economics 30, 427-464. 
[29] Hildreth, A. K. G. and A. J. Oswald (1997), Rent-sharing and wages: evidence from company and establishment panels, Journal of Labor Economics 15, 318337.

[30] Hübler, O. and A. König (1998), Produktmarkteinflüsse, Renten und Löhne: Eine semiparametrische Untersuchung, in: Gerlach, Knut (ed.): Ökonomische Analysen betrieblicher Strukturen und Entwicklungen: das Hannoveraner Firmenpanel. Frankfurt.

[31] Hübler, O. and U. Jirjahn (2003), Works councils and collective bargaining in Germany: The impact on productivity and wages, Scottish Journal of Political Economy 51, 471-492.

[32] Hunt, J. (2001), Post-unification wage growth in eastern Germany, Review of Economics and Statistics 87, 190-195.

[33] Lemieux, T. (2000), Estimating the effect of unions on wage inequality in a panel data model with comparative advantage and nonrandom selection, Journal of Labor Economics 16, 261-291.

[34] Moene, K. O., Wallerstein, M. and M. Hoel (1993), Bargaining structure and economic performance, in: Flanagan, R. J., Moene, K. O. and M. Wallerstein (eds.): Trade union behaviour, pay-bargaining and economic performance. Oxford.

[35] OECD (1997), Employment Outlook 1997. Paris.

[36] OECD (2004), Employment Outlook 2004. Paris.

[37] Oi, W. Y. and T. L. Idson (1999), Firm size and wages, in: Ashenfelter, O. and D. Card, Handbook of Labor Economics. Vol. 3, Amsterdam.

[38] Schmidt, C. M. and K. F. Zimmermann (1991), Work characteristics, firm size and wages, Review of Economics and Statistics 73, 705-710.

[39] Schnabel, C., Zagelmeyer, S. and S. Kohaut (2006), Collective bargaining structure and its determinants: an empirical analysis with British and German establishment level data, European Journal of Industrial Relations 12, 165-188.

[40] Soskice, D. (1990), Wage determination: The changing role of institutions in advanced industrialized countries, Oxford Review of Economic Policy 6, 36-61.

[41] Stephan, G. and K. Gerlach (2005), Wage settlements and wage setting: results from a multi-level model, Applied Economics 37, 2297-2306. 


\section{A Appendix}

\begin{tabular}{|c|c|}
\hline Variable & Definition \\
\hline $\begin{array}{l}\text { Establishment } \\
\text { size: }\end{array}$ & $\begin{array}{l}\text { Number of employees reported for the month June averaged } \\
\text { over the present and preceding year. }\end{array}$ \\
\hline $\begin{array}{l}\text { Per-capita } \\
\text { value added }\end{array}$ & $\begin{array}{l}\text { Value added is constructed by subtracting material costs from annual sales. } \\
\text { Per capita values are obtained by dividing value added by establishment } \\
\text { size. Nominal values are deflated by a sector-specific (two-digit) } \\
\text { producer price index. }\end{array}$ \\
\hline $\begin{array}{l}\text { Capital-labour } \\
\text { ratio }\end{array}$ & $\begin{array}{l}\text { Constructed by using the perpetual inventory method starting from the } \\
\text { capital value in the first observation year and using the information on } \\
\text { expansion investments. The initial capital value is proxied by dividing } \\
\text { investment expenditures in each establishment's first observation year } \\
\text { by a pre-period growth rate of investment, g, and a depreciation rate } \\
\text { of capital, d. Capital-stocks in subsequent periods are calculated by } \\
\text { adding real expansion investment expenditures. }{ }^{1)} \text { Nominal investment } \\
\text { expenditures are deflated by the producer price index of investment goods } \\
\text { of the Federal Statistical Office Germany. The capital-labour ratio is con- } \\
\text { structed by dividing the resulting capital proxy by establishment size. }\end{array}$ \\
\hline Works council & $\begin{array}{l}\text { Dummy=1 if works council is present. In some waves (1995 and } 1997) \\
\text { only those plants that enter the panel are asked to report the existence } \\
\text { of a works council. For the remaining establishments the missing } \\
\text { information is imputed based upon the information in the following year. }\end{array}$ \\
\hline Firm-level & Dummy $=1$ if establishment is covered by a firm-specific agreement. \\
\hline Industry-level & Dummy $=1$ if establishment is covered by an industry-specific agreement. \\
\hline
\end{tabular}

Table A1: Description of establishment variables 


\begin{tabular}{|c|c|c|}
\hline \multirow[t]{2}{*}{ Variable } & \multicolumn{2}{|c|}{ Mean Std.-Dev. } \\
\hline & \multicolumn{2}{|c|}{ Average change } \\
\hline$\Delta \mathrm{LOG}(\mathrm{WAGE})$ & 0.017 & 0.071 \\
\hline$\Delta$ TENURE (in months) & 11.952 & 0.407 \\
\hline$\Delta$ WHITECOLL $^{a)}$ & 0.019 & 0.136 \\
\hline$\triangle$ LOW-SKILLED & 0.015 & 0.120 \\
\hline$\triangle$ MEDIUM-SKILLED & 0.018 & 0.132 \\
\hline$\Delta$ HIGH-SKILLED & 0.004 & 0.062 \\
\hline \multicolumn{3}{|c|}{ EstABLISHMENT CHARACTERISTICS } \\
\hline$\triangle$ VALUE ADDED & 0.016 & 0.297 \\
\hline$\Delta \mathrm{LOG}(\mathrm{SIZE})$ & -.002 & 0.079 \\
\hline$\Delta \mathrm{CENT}$ & 0.048 & 0.214 \\
\hline$\Delta \mathrm{FIRM}$ & 0.037 & 0.188 \\
\hline$\triangle \mathrm{WCOUNCIL}$ & 0.015 & 0.122 \\
\hline$\Delta \mathrm{K} / \mathrm{L}$ & 0.047 & 0.260 \\
\hline Individuals & & 629,635 \\
\hline
\end{tabular}

Source: LIAB 1995-2007. All differences are averaged over individuals. Changes in per-capita value added and the capital-labour ratio are measured in $100,000 €$.

${ }^{a)}$ For categorical variables, mean values refer to a dummy variable indicating whether an individual experiences a change in the respective variable.

Table A2: Summary statistics differences 


\begin{tabular}{|c|c|c|c|c|c|c|}
\hline & Mean & Std.-Dev. & Mean & Std.-Dev. & Mean & Std.-Dev. \\
\hline $\begin{array}{l}\text { Transition to } \\
\text { from }\end{array}$ & \multicolumn{2}{|c|}{ No-coverage } & \multicolumn{2}{|c|}{ Industry-level } & \multicolumn{2}{|c|}{ Firm-level contract } \\
\hline A. No-coverage & \multicolumn{2}{|c|}{$(\mathrm{J}=357)$} & \multicolumn{2}{|c|}{$(\mathrm{J}=55)$} & \multicolumn{2}{|c|}{$(\mathrm{J}=9)$} \\
\hline LOG WAGE & 4.39 & 0.26 & 4.37 & 0.25 & 4.48 & 0.19 \\
\hline FEMALE & 0.28 & 0.24 & 0.20 & 0.21 & 0.13 & 0.14 \\
\hline AGE & 39.30 & 3.99 & 38.02 & 4.74 & 40.15 & 3.54 \\
\hline TENURE & 98.05 & 43.28 & 103.74 & 43.62 & 120.61 & 35.01 \\
\hline FOREIGN & 0.07 & 0.11 & 0.09 & 0.17 & 0.06 & 0.06 \\
\hline WHITECOLL & 0.36 & 0.27 & 0.28 & 0.25 & 0.49 & 0.38 \\
\hline LOW-SKILLED & 0.19 & 0.23 & 0.21 & 0.26 & 0.05 & 0.05 \\
\hline MEDIUM-SKILLED & 0.75 & 0.23 & 0.74 & 0.27 & 0.92 & 0.09 \\
\hline HIGH-SKILLED & 0.06 & 0.10 & 0.04 & 0.09 & 0.03 & 0.04 \\
\hline VALUE ADDED & 0.61 & 0.48 & 0.64 & 0.59 & 0.46 & 0.27 \\
\hline SIZE & 113.73 & 192.45 & 71.84 & 166.83 & 132.09 & 1216.14 \\
\hline WCOUNCIL & 0.29 & 0.44 & 0.18 & 0.34 & 0.50 & 0.5 \\
\hline $\mathrm{K} / \mathrm{L}$ & 0.56 & 0.78 & 0.83 & 3.02 & 0.46 & 0.27 \\
\hline B. Industry-level & \multicolumn{2}{|c|}{$(\mathrm{J}=98)$} & \multicolumn{2}{|c|}{$(\mathrm{J}=817)$} & \multicolumn{2}{|c|}{$(\mathrm{J}=33)$} \\
\hline LOG WAGE & 4.39 & 0.29 & 4.57 & 0.24 & 4.58 & 0.25 \\
\hline FEMALE & 0.26 & 0.24 & 0.20 & 0.19 & 0.19 & 0.20 \\
\hline AGE & 39.59 & 4.01 & 40.04 & 2.93 & 40.68 & 2.35 \\
\hline TENURE & 115.81 & 47.61 & 122.31 & 49.07 & 115.12 & 41.29 \\
\hline FOREIGN & 0.06 & 0.09 & 0.08 & 0.10 & 0.07 & 0.08 \\
\hline WHITECOLL & 0.34 & 0.26 & 0.36 & 0.23 & 0.37 & 0.23 \\
\hline LOW-SKILLED & 0.15 & 0.21 & 0.18 & 0.18 & 0.17 & 0.18 \\
\hline MEDIUM-SKILLED & 0.81 & 0.22 & 0.74 & 0.19 & 0.75 & 0.17 \\
\hline HIGH-SKILLED & 0.04 & 0.08 & 0.08 & 0.10 & 0.08 & 0.08 \\
\hline VALUE ADDED & 0.53 & 0.32 & 0.76 & 0.55 & 0.80 & 0.43 \\
\hline SIZE & 82.70 & 95.93 & 586.08 & $1,694.83$ & 410.45 & 545.18 \\
\hline WCOUNCIL & 0.32 & 0.45 & 0.77 & 0.41 & 0.94 & 0.24 \\
\hline $\mathrm{K} / \mathrm{L}$ & 0.55 & 1.59 & 0.96 & 2.14 & 0.68 & 0.72 \\
\hline
\end{tabular}


... continued

\begin{tabular}{|c|c|c|c|c|c|c|}
\hline \multirow[b]{2}{*}{$\begin{array}{l}\text { Transition to } \\
\text { from }\end{array}$} & Mean & Std.-Dev. & Mean & Std.-Dev. & Mean & Std.-Dev. \\
\hline & \multicolumn{2}{|c|}{ No-coverage } & \multicolumn{2}{|c|}{ Industry-level } & \multicolumn{2}{|c|}{ Firm-level contract } \\
\hline C. Firm-level contract & \multicolumn{2}{|c|}{$(\mathrm{J}=14)$} & \multicolumn{2}{|c|}{$(\mathrm{J}=20)$} & \multicolumn{2}{|c|}{$(\mathrm{J}=68)$} \\
\hline LOG WAGE & 4.50 & 0.21 & 4.61 & 0.23 & 4.59 & 0.20 \\
\hline FEMALE & 0.25 & 0.20 & 0.18 & 0.13 & 0.18 & 0.14 \\
\hline AGE & 38.36 & 2.81 & 40.07 & 2.59 & 40.43 & 2.35 \\
\hline TENURE & 100.90 & 40.73 & 129.21 & 59.24 & 123.21 & 51.40 \\
\hline FOREIGN & 0.06 & 0.06 & 0.04 & 0.05 & 0.07 & 0.09 \\
\hline WHITECOLL & 0.45 & 0.29 & 0.42 & 0.22 & 0.34 & 0.22 \\
\hline LOW-SKILLED & 0.13 & 0.14 & 0.11 & 0.12 & 0.18 & 0.16 \\
\hline MEDIUM-SKILLED & 0.82 & 0.16 & 0.77 & 0.19 & 0.75 & 0.15 \\
\hline HIGH-SKILLED & 0.05 & 0.06 & 0.11 & 0.15 & 0.07 & 0.07 \\
\hline VALUE ADDED & 0.65 & 0.30 & 0.83 & 0.64 & 0.80 & 0.44 \\
\hline SIZE & 172.12 & 144.18 & 251.37 & 317.01 & $1,590.10$ & $6,565.56$ \\
\hline WCOUNCIL & 0.63 & 0.50 & 0.82 & 0.39 & 0.97 & 0.17 \\
\hline $\mathrm{K} / \mathrm{L}$ & 0.75 & 0.77 & 0.59 & 0.76 & 1.40 & 2.80 \\
\hline
\end{tabular}

Source: LIAB 1999-2007.

Note: Per-capita value added and the capital-labour ratio are measured in 100,000 €.

All variables are averaged over establishments.

Table A1: Summary statistics by transitions

\begin{tabular}{|c|c|c|c|c|}
\hline $\begin{array}{l}\text { Transitions } \\
\text { from to: }\end{array}$ & Industry-level & Firm-level & No-coverage & \\
\hline Industry-level & 882 & 90 & 194 & $1,166(61.3 \%)$ \\
\hline Firm-level & 84 & 68 & 50 & $202(10.6 \%)$ \\
\hline \multirow[t]{2}{*}{ No-coverage } & 152 & 47 & 334 & $533(28.1 \%)$ \\
\hline & $1,118(58.8 \%)$ & $205(10.8 \%)$ & $578(30.4 \%)$ & 1,901 \\
\hline
\end{tabular}

Source: LIAB 1995-2007. The figures refer to the number of transitions.

The full original sample contains 1,695 establishments.

Table A4: Changes in contract status based on the raw transitions 


\begin{tabular}{|c|c|c|c|c|c|}
\hline \multicolumn{6}{|c|}{ "Average wage gain (loss) compared with workers in plants that always adopt the origin regime: } \\
\hline \multicolumn{6}{|l|}{ Transition } \\
\hline Period: ${ }^{a)}$ & $\mathrm{t}-\mathbf{2}$ & $\mathbf{t}-\mathbf{1}$ & $\mathrm{t}$ & $\mathbf{t}+\mathbf{1}$ & $\mathbf{t}+\mathbf{2}$ \\
\hline (1) Industry/Firm-Level & -.024 & 0.003 & $-.018^{* *}$ & $-.031^{* *}$ & 0.004 \\
\hline (2) Difference to $t-1$ & - & - & $-.021^{* *}$ & $-.034^{*}$ & 0.001 \\
\hline \multirow{2}{*}{ (3) Difference to $t-2$} & - & - & 0.006 & -.007 & $0.028^{*}$ \\
\hline & & & $(N=19,421, J=80)$ & & \\
\hline (1) Firm/Industry-Level & $0.032^{* *}$ & $-.032^{* *}$ & 0.007 & $0.035^{* *}$ & -.000 \\
\hline (2) Difference to $t-1$ & - & - & $0.039^{*}$ & $0.067^{* *}$ & 0.032 \\
\hline \multirow[t]{2}{*}{ (3) Difference to $t-2$} & - & - & -.025 & 0.003 & -.032 \\
\hline & & & $(N=14,012, J=73)$ & & \\
\hline (1) Industry/No-Cov. & $-.008^{*}$ & -.007 & -.011 & -.011 & $-.012^{*}$ \\
\hline (2) Difference to $t-1$ & - & - & -.004 & -.004 & -.005 \\
\hline \multirow[t]{2}{*}{ (3) Difference to $t-2$} & - & - & -.003 & -.003 & -.004 \\
\hline & & & $(N=13,719, J=184)$ & & \\
\hline (1) No-Cov./Industry & 0.005 & 0.000 & 0.000 & -.004 & 0.012 \\
\hline (2) Difference to $t-1$ & - & - & 0.000 & -.004 & 0.012 \\
\hline \multirow[t]{2}{*}{ (3) Difference to $t-2$} & - & - & -.005 & 0.001 & 0.007 \\
\hline & & & $(N=9,325, \quad J=143)$ & & \\
\hline (1) Firm/No-Cov. & $0.038^{* *}$ & -.007 & 0.014 & -.044 & -.020 \\
\hline (2) Difference to $t-1$ & - & - & 0.021 & -.037 & -.013 \\
\hline \multirow[t]{2}{*}{ (3) Difference to $t-2$} & - & - & -.024 & $-.082^{* *}$ & -.058 \\
\hline & & & $(N=5,765, J=42)$ & & \\
\hline (1) No-Cov./Firm & $0.025^{* *}$ & -.002 & $-.018^{*}$ & $0.020^{* *}$ & $0.010^{*}$ \\
\hline (2) Difference to $t-1$ & - & - & $-.016^{*}$ & 0.022 & 0.012 \\
\hline \multirow[t]{2}{*}{ (3) Difference to $t-2$} & - & - & $-.043^{* *}$ & -.005 & -.015 \\
\hline & & & $(N=5,145, J=42)$ & & \\
\hline
\end{tabular}

Source: LIAB 1999-2007. The estimates of the wage premiums are obtained by estimating the interacted spell differenced specification using the respective subsamples of establishments (those that experience the change in contract status and those that retain the origin regime). Standard errors are adjusted for clustering at the establishment-level. $J$ refers to the number of establishments and $N$ refers to the number of individuals experiencing the transitions. ${ }^{a)} t$ refers to the year of the transition. A transition in year $t$ is defined as a change in contract status between year $t-1$ and $t$. ${ }^{* * *}$ Significant at $1 \%-,{ }^{* *} 5 \%-,{ }^{*} 10 \%$-level.

Table A5: Analysis of separate transitions using the raw transitions 